\title{
HUBUNGAN PERSALINAN PREMATUR DENGAN KEJADIAN ASFIKSIA NEONATORUM DI RUANG BERSALIN RSU DR. WAHIDIN SUDIRO HUSODO KOTA MOJOKERTO
}

\author{
Bety Mayasari $^{1}$, Dian Fitra Arismawati ${ }^{1}$, Titiek Idayanti ${ }^{1}$, Riska Aprilia Wardani ${ }^{1}$
}

${ }^{1}$ Program Studi Kebidanan, STIKES Dian Husada Mojokerto

\author{
*Correspondence: \\ Bety Mayasari \\ Email: mayasari.bety@gmail.com
}

\begin{abstract}
Background: Persalinan prematur merupakan masalah yang selalu menjadi perhatian karena menjadi salah satu penyebab utama kematian neonatal. Persalinan prematur adalah persalinan yang terjadi ketika usia kehamilan belum mencapai 37 minggu. Persalinan prematur menjadi penyebab tingginya angka kematian bayi (AKB) karena kondisi bayi yang masih lemah karena imaturitas organ, salah satunya adalah paru-paru.

Purpose: Tujuan penelitian ini adalah mengetahui adakah hubungan persalinan prematur dengan kejadian asfiksia neonatorum.

Method: Desain penelitian yang digunakan adalah Cross-Sectional, yaitu suatu jenis penelitian yang menekankan pada waktu pengukuran/observasi data variabel independen dan variabel dependen hanya satu kali dalam satu saat. Dalam penelitian ini sampel diambil dengan teknik consecutive sampling, variabel dalam penelitian ini ada 2 yaitu variabel independent (variabel bebas) adalah persalinan prematur dan variabel dependent (variabel tergantung) adalah kejadian asfiksia neonatorum. Cara pengambilan data dengan menggunakan lembar observasi secara langsung kepada responden. Pengolahan data menggunakan uji korelasi Spearman.

Results: Hasil penelitian menunjukkan bahwa hubungan persalinan prematur dengan kejadian asfiksia neonatorum yaitu asfiksia ringan terjadi pada 4 bayi (100\%) yang dilahirkan oleh ibu yang mengalami persalinan dengan usia kehamilan 32-36 minggu. Dengan menggunakan uji Korelasi Spearman dengan tingkat kemaknaan/signifikasi 0,00 $(\alpha<0.05)$, yang berarti bahwa Ho ditolak dan Hi diterima. Serta didapatkan hasil koofisien korelasi $(\rho)=0,875$, yang menyatakan bahwa terdapat hubungan sangat kuat antara dua variabel yaitu persalinan prematur dengan kejadian asfiksia neonatorum.

Conclusion: Berdasarkan hasil penelitian, ibu hamil dan keluarga diharapkan untuk teratur melakukan kunjungan ANC, serta bagi tenaga kesehatan untuk mempertahankan pro aktif dalam memberikan ANC Terpadu, sehingga resiko dapat terdeteksi lebih awal dan komplikasi akan mendapat penanganan secepatnya.
\end{abstract}

Key words: Persalinan premature, asfiksia neonatorum

\section{PENDAHULUAN}

Angka persalinan prematur di seluruh dunia berkisar antara 10-20 persen. Indonesia sendiri memiliki angka kelahiran prematur sekitar 19\%. Di negara-negara maju, insiden persalinan prematur dapat dikurangi dengan kualitas kesehatan yang lebih baik dan berbagai tindakan pencegahan (Sony Prabowo, 2011).
Proporsi penyebab kematian neonatal berdasarkan Riskesdas (2007) di kelompok umur 0-7 hari antara lain gangguan pernapasan/kesulitan bernafas saat lahir $36,9 \%$, prematur $32,4 \%$, sepsis $12 \%$, hipotermi 6,8\%, kelainan darah/ikterus 6,6\% (DepKes RI, 2011). Menurut hasil study pendahuluan yang dilakukan di Ruang Bersalin RSU Dr. Wahidin Sudiro 
Husodo Kota Mojokerto pada bulan Juni 2015 proporsi penyebab kematian neonatal antara lain prematur, asfiksia neonatorum, sepsis, pneumonia dan MAS (Meconial Aspiration Syndrom). Serta diperoleh data kelahiran bayi pada bulan Juni 2015 sejumlah 69 bayi. Bayi yang lahir dari persalinan prematur sejumlah 9 bayi (13\%) dan dari jumlah tersebut terdapat 5 bayi $(55,6 \%)$ mengalami asfiksia neonatorum. Sedangkan dari data kematian bayi pada bulan Juni 2015 di RSU Dr. Wahidin Sudiro Husodo, 4 bayi (80\%) yang lahir prematur dan mengalami asfiksia neonatorum tersebut berakhir dengan kematian.

Menurut Abraham M. Rudolf, dkk (2006), persalinan Prematur/Preterm didefinisikan sebagai dimulainya kontraksi uterus teratur yang menyebabkan perubahan serviks sebelum usia gestasi 37 minggu, yang mengindikasikan suatu resiko dalam sebuah persalinan. Hipoksia sering ditemukan pada bayi prematur. Kejadian ini umumnya telah dimulai sejak janin di kandungan, berupa gawat janin atau terjadinya stres janin pada waktu proses kelahirannya. Selain hal tersebut, paru-paru pada bayi prematur mengalami kekurangan bahan surfaktan. Hal ini menyebabkan bayi prematur sulit menyesuaikan diri dengan kehidupan luar rahim, sehingga mengalami banyak gangguan kesehatan (Musbikin, 2005). Akibatnya bayi prematur mengalami asfiksia neonatorum, yang merupakan suatu kejadian kedaruratan neonatal dan sangat berisiko untuk terjadinya kematian. Asfiksia neonatorum terjadi karena bayi tidak dapat bernafas secara spontan dan teratur segera setelah lahir keadaan tersebut dapat disertai dengan adanya hipoksia, hiperkapnea dan sampai ke asidosis (Hidayat, 2005). Asfiksia neonatorum ditentukan dengan nilai APGAR yang dihitung pada menit ke 1 dan menit ke 5 sesudah lahir. Nilai Apgar digunakan untuk menilai kriteria klinis bayi baru lahir yang menunjukkan beratnya asfiksia yang diderita dan baik sekali sebagai pedoman untuk menentukan penanganan selanjutnya.

Penatalaksanaan yang tepat dan efektif pada asfiksia neonatorum dalam beberapa menit pertama kehidupan dapat mempengaruhi hasil jangka panjang terhadap kehidupan bayi prematur. Penatalaksanaan tergantung pada derajat asfiksia neonatorum yang telah dinilai dengan APGAR. Perawatan bayi baru lahir dengan asfiksia ringan cukup dengan perawatan biasa sedangkan ketrampilan resusitasi neonatal sangat penting untuk dipelajari oleh semua tenaga profesional layanan medis yang terlibat dalam pertolongan bayi baru lahir dengan asfiksia sedang dan berat. Oleh karena eratnya kaitan antara persalinan prematur terhadap kejadian asfiksia neonatorum. Maka penulis tertarik untuk melakukan penelitian lebih lanjut yaitu mengenai hubungan persalinan prematur dengan kejadian asfiksia neonatorum di Ruang Bersalin RSU Dr. Wahidin Sudiro Husodo.

\section{METODE DAN BAHAN}

Penelitian ini menggunakan rancangan penelitian korelasional, dimana peneliti mengkaji hubungan antara variabel. Desain penelitian yang digunakan adalah Cross-Sectional, yaitu suatu jenis penelitian yang menekankan pada waktu pengukuran/observasi data variabel independen dan variabel dependen hanya satu kali dalam satu saat. Populasi target dalam penelitian ini adalah seluruh ibu dan bayi dengan persalinan prematur di RSU Dr. Wahidin Sudiro Husodo. Sedangkan, populasi terjangkau dalam penelitian ini adalah seluruh ibu dan bayi dengan persalinan prematur di Ruang Bersalin RSU Dr. Wahidin Sudiro Husodo Kota Mojokerto mulai 1-31 Januari 2015. Untuk 
mengetahui adanya hubungan antar variabel, peneliti menggunakan uji Korelasi Spearman dengan tingkat kemaknaan $(\alpha)=$ 0,05 dengan menggunakan program SPSS.

\section{HASIL PENELITIAN}

\section{Karakteristik Responden Berdasarkan Usia Ibu.}

Tabel 1. Karakteristik Responden Berdasarkan Usia Ibu di Ruang Bersalin RSU Dr. Wahidin Sudiro Husodo Kota Mojokerto pada tanggal 1-31 Januari 2015.

\begin{tabular}{|c|c|c|c|}
\hline No & Umur Ibu & Jumlah & Prosentase \\
\hline 1. & $<20$ tahun & 4 & $36 \%$ \\
\hline 2. & $21-35$ tahun & 4 & $36 \%$ \\
\hline 3. & $>35$ tahun & 3 & $28 \%$ \\
\hline \multicolumn{2}{|c|}{ Total } & 11 & $100 \%$ \\
\hline
\end{tabular}

Berdasarkan tabel 1 dapat menunjukkan bahwa sebagian besar distribusi responden berdasarkan umur ibu yang mengalami persalinan prematur yaitu berumur $<20$ tahun sejumlah 4 responden $(36 \%)$.

\section{Karakteristik Responden Berdasarkan Etiologi Persalinan Prematur.}

Tabel 2. Karakteristik Responden Berdasarkan Etiologi Persalinan Prematur di Ruang Bersalin RSU Dr. Wahidin Sudiro Husodo Kota Mojokerto pada tanggal 1-31 Januari 2015.

\begin{tabular}{|c|l|c|c|}
\hline No & \multicolumn{1}{|c|}{$\begin{array}{c}\text { Etiologi } \\
\text { Persalinan Prematur }\end{array}$} & Jumlah & Prosentase \\
\hline 1. & Trauma & 4 & $37 \%$ \\
\hline 2. & KPD (Inkompetensi Serviks) & 2 & $18 \%$ \\
\hline 3. & Gemelli & 2 & $18 \%$ \\
\hline 4. & Plasenta Previa & 1 & $9 \%$ \\
\hline 5. & Riwayat prematur sebelumnya & 1 & $9 \%$ \\
\hline 6. & Hipertensi & 1 & $9 \%$ \\
\hline \multicolumn{2}{|c|}{ Total } & 11 & $100 \%$ \\
\hline
\end{tabular}

Berdasarkan hasil penelitian diatas dapat diketahui bahwa etiologi sebagian besar responden yang mengalami persalinan prematur adalah trauma sejumlah 4 responden (37\%).

\section{Karakteristik Responden Berdasarkan Berat Badan Lahir Bayi.}

Berdasarkan tabel 3 dapat menunjukkan bahwa distribusi responden berdasarkan berat badan lahir bayi dari ibu dengan persalinan prematur sebagian besar memiliki berat badan lahir rendah antara 1500-2500gram sejumlah 6 bayi (55\%).

Tabel 3. Karakteristik Responden Berdasarkan Berat Badan Lahir Bayi di Ruang Bersalin RSU Dr. Wahidin Sudiro Husodo Kota Mojokerto pada tanggal 1-31 Januari 2015.

\begin{tabular}{|c|c|c|c|}
\hline No & Berat Badan Lahir & Jumlah & Prosentase \\
\hline 1. & BBLN (> 2500 gram) & 1 & $9 \%$ \\
\hline 2. & BBLR (1500-2500 gram) & 6 & $55 \%$ \\
\hline 3. & BBLSR (1000-1500 gram) & 2 & $18 \%$ \\
\hline 4. & BBLER (<1000 gram) & 2 & $18 \%$ \\
\hline \multicolumn{2}{|c|}{ Total } & 11 & $100 \%$ \\
\hline
\end{tabular}

\section{Karakteristik Responden Berdasarkan Usia Kehamilan.}

Tabel 4. Karakteristik Responden Berdasarkan Usia Kehamilan di Ruang Bersalin RSU Dr. Wahidin Sudiro Husodo Kota Mojokerto pada tanggal 1-31 Januari 2015.

\begin{tabular}{|c|c|c|c|}
\hline No & Persalinan Prematur & Jumlah & Prosentase \\
\hline 1. & $\begin{array}{c}\text { Prematur (UK 32-36 } \\
\text { minggu) }\end{array}$ & 4 & $36 \%$ \\
\hline 2. & $\begin{array}{c}\text { Sangat Prematur (UK } \\
28-32 \text { minggu) }\end{array}$ & 3 & $28 \%$ \\
\hline 3. & $\begin{array}{c}\text { Ekstrim Prematur (UK } \\
20-27 \text { minggu) }\end{array}$ & 4 & $36 \%$ \\
\hline \multicolumn{2}{|c|}{ Total } & 11 & $100 \%$ \\
\hline
\end{tabular}

Dari tabel 4 diketahui bahwa sebagian besar klasifikasi persalinan prematur berdasarkan usia kehamilan adalah prematur (32-36 minggu) sejumlah 4 bayi (36\%) dan ekstrim prematur (20-27 minggu) sejumlah 4 bayi (36\%). 
Karakteristik Responden Berdasarkan Klasifikasi Kejadian Asfiksia Neonatorum Berdasarkan APGAR SKOR.

Tabel 5. Karakteristik Responden Berdasarkan Usia Kehamilan di Ruang Bersalin RSU Dr. Wahidin Sudiro Husodo Kota Mojokerto pada tanggal 1-31 Januari 2015.

\begin{tabular}{|c|c|c|c|}
\hline No & $\begin{array}{l}\text { Kejadian Asfiksia } \\
\text { Neonatorum }\end{array}$ & Jumlah & Prosentase \\
\hline 1. & Asfiksia Ringan (AS 7-10) & 4 & $36 \%$ \\
\hline 2. & Asfiksia Sedang (AS 4-6) & 3 & $28 \%$ \\
\hline 3. & Asfiksia Berat (AS 0-3) & 4 & $36 \%$ \\
\hline & Total & 11 & $100 \%$ \\
\hline
\end{tabular}

Berdasarkan data pada tabel 5 diketahui bahwa klasifikasi kejadian asfiksia neonatorum berdasarkan APGAR SKOR bayi yang dilahirkan ibu dengan persalinan prematur sebagian besar adalah asfiksia ringan (AS 7-10) sejumlah 4 bayi (36\%) dan asfiksia berat (AS 0-3) sejumlah 4 bayi (36\%).

\section{Hubungan Persalinan Prematur dengan Kejadian Asfiksia Neonatorum.}

Tabel 6. Tabulasi Silang Hubungan Persalinan Prematur dengan Kejadian Asfiksia Neonatorum di Ruang Bersalin RSU Dr. Wahidin Sudiro Husodo Kota Mojokerto pada tanggal 1-31 Januari 2015.

\begin{tabular}{|c|c|c|c|c|c|c|c|}
\hline \multirow{2}{*}{$\begin{array}{c}\text { Klasifikasi } \\
\text { Persalinan } \\
\text { Prematur } \\
\begin{array}{c}\text { Berdasarkan } \\
\text { Usia } \\
\text { Kehamilan }\end{array}\end{array}$} & \multicolumn{5}{|c|}{$\begin{array}{c}\text { Klasifikasi Kejadian Asfiksia Neonatorum } \\
\text { Berdasarkan APGAR SKOR }\end{array}$} & \multirow{2}{*}{ Total } \\
\cline { 2 - 8 } & \multicolumn{2}{|c|}{$\begin{array}{c}\text { Asfiksia } \\
\text { (AS 7-10) }\end{array}$} & \multicolumn{2}{|c|}{$\begin{array}{c}\text { Asfiksia } \\
\text { Sedang (AS 4- }\end{array}$} & \multicolumn{2}{|c|}{$\begin{array}{c}\text { Asfiksia Berat } \\
\text { (AS 0-3) }\end{array}$} & \\
\cline { 2 - 8 } & $\mathrm{N}$ & $\%$ & $\mathrm{~N}$ & $\%$ & $\mathrm{~N}$ & $\%$ & \\
\hline $\begin{array}{c}\text { Prematur } \\
\text { (UK 32-36 } \\
\text { minggu) }\end{array}$ & 4 & $100 \%$ & 0 & $0 \%$ & 0 & $0 \%$ & 4 \\
\hline $\begin{array}{c}\text { Sangat } \\
\text { Prematur } \\
\text { (UK 28-32 } \\
\text { minggu) }\end{array}$ & 0 & $0 \%$ & 2 & $67 \%$ & 1 & $25 \%$ & 3 \\
\hline $\begin{array}{c}\text { Ekstrim } \\
\text { Prematur } \\
\text { (UK 20-27 } \\
\text { minggu) }\end{array}$ & 0 & $0 \%$ & 1 & $33 \%$ & 3 & $75 \%$ & 4 \\
\hline Total & 4 & $100 \%$ & 3 & $100 \%$ & 4 & $100 \%$ & 11 \\
\hline
\end{tabular}

Berdasarkan data pada tabel 6 diketahui bahwa hubungan persalinan prematur dengan kejadian asfiksia neonatorum yaitu asfiksia ringan terjadi pada 4 bayi (100\%) yang dilahirkan oleh ibu yang mengalami persalinan dengan usia kehamilan 32-36 minggu. Asfiksia sedang terjadi pada 3 bayi yang terdiri dari 2 bayi $(67 \%)$ yang dilahirkan dengan usia kehamilan 28-32 minggu dan 1 bayi (33\%) yang dilahirkan dengan usia kehamilan 2027 minggu. Sedangkan asfiksia berat terjadi pada 4 bayi yang terdiri dari 1 bayi (25\%) yang dilahirkan dengan usia kehamilan 2832 minggu dan 3 bayi (75\%) yang dilahirkan dengan usia kehamilan 20-27 minggu.

Tabel 7. Hasil Uji Korelasi Spearmen Rho terhadap Hubungan Persalinan Prematur dengan Kejadian Asfiksia Neonatorum di Ruang Bersalin RSU Dr. Wahidin Sudiro Husodo Kota Mojokerto pada tanggal 1-31 Januari 2015.

\begin{tabular}{|c|c|c|c|c|}
\hline & & & $\begin{array}{c}\text { Persalinan } \\
\text { Prematur }\end{array}$ & $\begin{array}{c}\text { Kejadian } \\
\text { Asfiksia } \\
\text { Neonatorum }\end{array}$ \\
\hline \multirow[t]{6}{*}{$\begin{array}{l}\text { Spearman's } \\
\text { rho }\end{array}$} & \multirow[t]{3}{*}{$\begin{array}{l}\text { Persalinan } \\
\text { Prematur }\end{array}$} & \begin{tabular}{|l|} 
Correlation \\
Coefficient
\end{tabular} & 1.000 & $.875^{* *}$ \\
\hline & & Sig. (2-tailed) & & .000 \\
\hline & & $\mathrm{N}$ & 11 & 11 \\
\hline & \multirow{3}{*}{$\begin{array}{l}\text { Kejadian } \\
\text { Asfiksia } \\
\text { Neonatorum }\end{array}$} & $\begin{array}{l}\text { Correlation } \\
\text { Coefficient }\end{array}$ & $.875^{* * *}$ & 1.000 \\
\hline & & Sig. (2-tailed) & .000 & . \\
\hline & & $\mathrm{N}$ & 11 & 11 \\
\hline
\end{tabular}

Berdasarkan tabel 7 dapat diketahui bahwa hasil analisa data dengan SPSS 17 menggunakan uji Korelasi Spearman dengan tingkat kemaknaan/signifikasi 0,00 $(\alpha<0.05)$, yang berarti bahwa Ho ditolak dan Hi diterima. Serta didapatkan hasil koofisien korelasi $(\rho)=0,875$, yang menyatakan bahwa terdapat hubungan sangat kuat antara dua variabel yaitu 
persalinan prematur dengan kejadian asfiksia neonatorum.

\section{PEMBAHASAN}

\section{Persalinan Prematur}

Berdasarkan tabel diatas, sebagian besar klasifikasi persalinan prematur berdasarkan usia kehamilan adalah prematur (32-36 minggu) sejumlah 4 bayi $(36 \%)$ dan ekstrim prematur (20-27 minggu) sejumlah 4 bayi (36\%).

Menurut Paulette S. Haws (2008), persalinan prematur yaitu adanya kontraksi uterus teratur dengan dilatasi serviks dan effacement sebelum usia gestasi 37 minggu. Terdapat tiga klasifikasi persalinan prematur menurut Krisnandi (2009) berdasarkan usia kehamilannya, yaitu prematur (UK 32-36 minggu), sangat prematur (UK 28-32 minggu), dan ekstrim prematur (UK 20-27 minggu). Usia kehamilan merupakan faktor penting yang harus diperhatikan dalam persalinan, karena usia kehamilan berfungsi untuk menentukan fase-fase pertumbuhan dan perkembangan organ dalam janin. Semakin sedikit usia kehamilan, berarti bahwa semakin imatur pula organ yang terbentuk, salah satunya yaitu paru-paru. Oleh karena itulah, pada bayi prematur terjadi defisiensi surfaktan paru yang dapat menyebabkan kegagalan nafas segera setelah lahir yang disebut dengan asfiksia neonatorum.

Terjadinya persalinan prematur dapat dipengaruhi oleh empat faktor utama yaitu faktor iatrogenik (indikasi medis pada ibu/janin), faktor maternal, faktor janin dan faktor perilaku. Terlihat pada tabel 4.1 bahwa sebagian besar distribusi responden berdasarkan umur ibu yang mengalami persalinan prematur yaitu berumur $<20$ tahun sejumlah 4 responden $(36 \%)$. Hal ini menunjukkan bahwa persalinan prematur pada penelitian ini lebih banyak terjadi pada kelompok umur ibu resiko tinggi yaitu pada kelompok umur < 20 tahun. Umur ibu adalah salah satu faktor maternal sebagai penyebab terjadinya persalinan prematur. Menurut Widyastuti (2009), umur reproduksi yang sehat dan aman adalah umur 20 - 35 tahun. Kehamilan di usia kurang dari 20 tahun secara fisik dan psikis masih kurang, misalnya dalam perhatian untuk pemenuhan kebutuhan zat-zat gizi selama kehamilannya sehingga kelompok umur ini beresiko tinggi mengalami penyulit obstetri serta morbiditas dan mortalitas perinatal.

Sedangkan pada tabel 4.2, menunjukkan bahwa etiologi sebagian besar responden yang mengalami persalinan prematur adalah trauma sejumlah 4 responden (37\%). Hal ini membuktikan faktor lain yang mempengaruhi persalinan prematur pada faktor maternal yaitu trauma. Responden yang mengalami trauma dalam penelitian ini antara lain trauma setelah berhubungan badan dengan suami. Menurut Bobak (2004), melakukan hubungan seksual dapat terjadi trauma kerena menimbulkan rangsangan pada uterus sehingga terjadi kontraksi uterus. Sperma yang mengandung hormon prostaglandin merupakan hormon yang dapat merangsang kontraksi uterus. Pemberian pendidikan kesehatan tentang kebutuhan seksual suami istri selama hamil diharapkan mampu mengurangi resiko terjadinya persalinan prematur karena trauma.

\section{Kejadian Asfiksia Neonatorum}

Berdasarkan diatas, klasifikasi kejadian asfiksia neonatorum berdasarkan APGAR SKOR bayi yang dilahirkan ibu dengan persalinan prematur sebagian besar adalah asfiksia ringan (AS 7-10) sejumlah 4 bayi (36\%) dan asfiksia berat (AS 0-3) sejumlah 4 bayi (36\%).

Menurut Winkjosastro (2007), asfiksia neonatorum adalah suatu keadaan dimana bayi baru lahir gagal bernafas spontan dan teratur segera setelah lahir sehingga dapat menurunkan $\mathrm{O} 2$ dan meningkatkan $\mathrm{CO} 2$ yang menimbulkan akibat buruk dalam kehidupan lebih lanjut. Derajat kegagalan nafas bayi pada asfiksia neonatorum dapat dinilai menggunakan 
APGAR SKOR yang terdiri dari 5 kriteria penilaian yaitu : warna kulit (Appereance), denyut nadi (Pulse), reflek (Grimace), tonus otot (Activity), dan usaha bernafas bayi (Respiration).

Klasifikasi asfiksia neonatorum berdasarkan derajat asfiksianya dibagi menjadi tiga yaitu asfiksia ringan (APGAR SKOR 7-10), asfiksia sedang (APGAR SKOR 4-6) dan asfiksia berat (APGAR SKOR 0-3) (Steven P. Shelov, 2005). APGAR SKOR tersebut dihitung pada waktu 1 menit dan 5 menit pertama setelah kelahiran. APGAR SKOR pada menit pertama berfungsi untuk menentukan diagnosa serta klasifikasi dari asfiksia neonatorum yang dialami bayi tersebut. Perhitungan pada menit pertama ini sangat berguna untuk merencanakan penatalaksaan lanjutan dari asfiksia neonatorum, serta dilakukan evaluasi kembali setelah lima menit.

\section{Hubungan Persalinan Prematur dengan Kejadian Asfiksia Neonatorum}

Pada tabel diatas, menunjukkan bahwa hubungan persalinan prematur dengan kejadian asfiksia neonatorum yaitu asfiksia ringan terjadi pada 4 bayi (100\%) yang dilahirkan oleh ibu yang mengalami persalinan dengan usia kehamilan 32-36 minggu. Asfiksia sedang terjadi pada 3 bayi yang terdiri dari 2 bayi $(67 \%)$ yang dilahirkan dengan usia kehamilan 28-32 minggu dan 1 bayi (33\%) yang dilahirkan dengan usia kehamilan 20-27 minggu. Sedangkan asfiksia berat terjadi pada 4 bayi yang terdiri dari 1 bayi $(25 \%)$ yang dilahirkan dengan usia kehamilan 28-32 minggu dan 3 bayi (75\%) yang dilahirkan dengan usia kehamilan 20-27 minggu.

Berdasarkan tabel 4.7 terlihat hasil analisa data dengan SPSS 17 menggunakan uji Korelasi Spearman dengan tingkat kemaknaan/signifikasi 0,00 $(\alpha<0.05)$, yang berarti bahwa Ho ditolak dan Hi diterima. Serta didapatkan hasil koofisien korelasi $(\rho)=0,875$, yang menyatakan bahwa terdapat hubungan sangat kuat antara dua variabel yaitu persalinan prematur dengan kejadian asfiksia neonatorum.

Hubungan antara kedua hal tersebut adalah persalinan prematur merupakan salah satu penyebab terjadinya asfiksia neonatorum. Menurut Winkjosastro (2007), terdapat empat faktor utama yang menjadi etiologi asfiksia neonatorum,yaitu faktor ibu, faktor plasenta, faktor janin dan faktor proses persalinan. Persalinan prematur termasuk dalam faktor janin. Persalinan prematur beresiko menyebabkan terjadinya asfiksia neonatorum pada bayi yang dilahirkan karena imaturitas organ terutama paru-paru yang menyebabkan kegagalan bernafas spontan pada menit awal kelahirannya. Menurut dr. Purnawan Senoaji, SpOg (2012), paru-paru terbentuk dan mengalami proses pematangan secara bertahap. Organ ini merupakan organ yang terbentuk sempurna paling akhir yaitu di usia kehamilan 37-38 minggu. Pada penelitian ini, terdapat perbedaan pada derajat asfiksia neonatorum yang dialami bayi prematur sesuai dengan klasifikasi kelompok usia kehamilannya. Semakin besar usia kehamilan berarti semakin matur paru-paru bayi tersebut. Semakin besar usia kehamilan, maka volume surfaktan paruparu semakin mendekati normal sehingga kemampuan ekspansi paru juga semakin baik. Terbukti pada hasil penelitian bahwa bayi prematur yang lahir dengan klasifikasi usia kehamilan prematur (32-36 minggu), seluruhnya mengalami asfiksia ringan (A-S 7-10) yang dapat ditangani dengan perawatan bayi baru lahir biasa. Begitu pula sebaliknya, semakin sedikit usia kehamilan berarti semakin imatur paru-parunya dan semakin sedikit cairan surfaktan yang dimiliki paru-paru tersebut. Oleh karena itu, bayi prematur yang masuk dalam kategori usia kehamilan sangat prematur (28-32 minggu) dan ekstrim prematur (2027 minggu) sangat beresiko mengalami kegagalan nafas saat lahir. Hal ini terbukti pada hasil penelitian bahwa bayi yang lahir dengan rentang usia kehamilan tersebut, sebagian besar mengalami asfiksia berat 
(A-S 0-3) yang memerlukan penatalaksanaan berupa resusitasi neonatal dan membutuhkan pemeriksaan serta penanganan intensif lanjutan.

Pemeriksaan lanjutan menurut Firmansyah (2000), salah satunya adalah pemeriksaan untuk menentukan rasio lesitin-sfngomielin dan amniosintesis yaitu memeriksa tingkat maturitas paru dan volume cairan surfaktan sehingga bayi mendapatkan penanganan berupa penambahan cairan surfaktan untuk meningkatan ekspansi paru bayi. Penatalaksanaan lain menurut Marjono (2008) yaitu penggunaan sumber udara tekan (CPAP, neopuff) untuk memenuhi kebutuhan oksigenasi bayi karena paruparu bayi masih imatur sehingga mudah mengalami kerusakan dan membutuhkan ventilasi tekanan positif untuk mengembangkan paru-parunya. Menurut Depkes RI (2008), penatalaksaan lain yang tidak kalah penting untuk bayi prematur yaitu memenuhi kebutuhan termoregulasi, karena kulit bayi yang tipis dengan permukaan tubuh yang relatif luas serta kurangnya lemak tubuh sehingga memudahkan bayi kehilangan panas. Keadaan hipotermia/stress dingin (suhu tubuh $<36,5^{\circ} \mathrm{C}$ ) ini dapat memburuk prognosa bayi prematur dan menyebabkan kondisi yang mengancam jiwa (Widodo, 2009).

\section{SIMPULAN}

Berdasarkan hasil penelitian penelitian tentang hubungan persalinan prematur dengan kejadian asfiksia neonatorum, didapatkan bahwa bayi yang lahir prematus sebagian besar mengalami asfiksia sedang. Hasil uji hasil analisa data dengan SPSS 17 menggunakan uji Korelasi Spearman dengan tingkat kemaknaan/ signifikasi $0,00 \quad(\alpha<0.05)$, yang berarti bahwa Ho ditolak dan Hi diterima.

\section{SARAN}

1. Bagi institusi pendidikan diharapkan dapat dijadikan referensi untuk menambah pengetahuan bagi mahasiswa mengenai persalinan prematur dengan asfiksia. Bagi peneliti selanjutnya disarankan lebih memahami kembali hasil penelitian ini dan tertarik untuk melanjutkan penelitian dengan faktor lain yang berhubungan dengan asfiksia neonatorum atau persalinan prematur. Bagi peneliti diharapkan dapat menambah wawasan dalam upaya mengkaji permasalahan persalinan prematur dengan kejadian asfiksia.

2. Bagi pelayanan kesehatan diharapkan agar dapat menyediakan protap untuk pelaksanaan penanganan asfiksia. Sehingga tidak terjadi keterlambatan penanganan asfiksia.

\section{DAFTAR PUSTAKA}

1. Abraham M. Rudolf, dkk. 2006. Buku Ajar Pediatri Volume 1. Jakarta : EGC.

2. Aliyah Anna, dkk. 1997. Resusitasi Neonatal. Jakarta : Perkumpulan perinatologi Indonesia (Perinasia).

3. Aminullah,A. (2005). Ilmu Kebidanan. Jakarta : YayasanBinaPustakaSarwono Prawirohardjo.

4. Arikunto. 2006. Prosedur Penelitian Suatu Pendekatan Praktek. Jakarta : PT. Rineka Cipta.

5. Bobak; Lowdermilk; Jensen. 2004. Buku Ajar Keperawatan Maternitas. Ed. Alih bahasa : Renata Komalasari. Jakarta : EGC.

6. Cunningham, G. F, Gant. F, N, Leveno. $\mathrm{J}, \mathrm{K}$, at al. 2006. Obstetri Williams Volume 1. Jakarta : EGC.

7. Dahlan, M. Sopiyudin. 2008. Statistik untuk Kedokteran dan Kesehatan, Deskriptif, Bivariat, dan Multivariat dilengkapi Aplikasi dengan 
Menggunakan SPSS, edisi 3. Jakarta : Salemba Medika.

8. DepKes RI. 2011. Setiap hari, lebih dari 400 bayi (0-11 bulan) meninggal di Indonesia. Jakarta : Kementrian Kesehatan RI (http://www.gizikia.depkes.go.id/wpcontent/uploads/downloads/2011/01/M ateri-Advokasi-BBL.pdf diakses tanggal 10 Nov 2012).

9. Depkes RI. 2008. Pencegahan dan Penatalaksanaan Asfiksia Neonatorum. Jakarta : Kementrian Kesehatan RI.

10. Eriyanti Indrasanto Dr. Sp. A (K),dkk. 2008. Paket Pelatihan Pelayanan Obstetri dan Neonatal Emergensi Komprehensif (PONEK) : Asuhan Keperawatan Esensial. Jakarta : Bina Pelayanan Medik \& JNPK-KR.

11. Hidayat. 2005. Pengantar Ilmu Keperawatan Anak. Jakarta : Salemba Medika.

12. Krisnadi, R.S., Effendi, S.J. \& Pribadi, A. (2009). Prematuritas, Bandung : Refika Aditama.

13. Marjono AB. 2008. Resusitasi dan Perawatan Intensif Neonatus. Jakarta : FKUI.

14. Musbikin Imam. (2005). Panduan bagi ibu hamil \& melahirkan, Yogyakarta : Mitra Pustaka.

15. Nazir. 2005. Metodologi Penelitian. Bogor : Ghalia Pustaka Utama.

16. Norwitz, E.R \& Schorge J.O. 2008. At a Glance Obstetri dan Ginekologi Edisi 2. Jakarta : Salemba Medika.

17. Nursalam. 2008. Konsep dan Penerapan Metodologi Penelitian Ilmu Keperawatan : Pedoman Skripsi, Tesis dan Instrumen Penelitian Keperawatan. Jakarta : Salemba Medika.

18. Oxorn. 2003. Pelayanan Obstetri dan Ginekologi. Jakarta: EGC.

19. Purnawan Senoaji,Dr. Sp. A. 2012. Tahap Perkembangan Janin. http://tanyadokterspog.forumid.net/t89 -trimester-ketiga-kehamilan, diakses tanggal 16 Maret 2013.
20. Paulette S. Haws. 2008. Asuhan Neonatus Rujukan Cepat. Jakarta : EGC.

21. Prawirohardjo, S. 2002. Ilmu Kebidanan. Jakarta : Yayasan Bina Pustaka Sarwono Prawirohardjo.

22. Riskesdas. 2007. Inilah Penyebab Kematian Bayi Paling Sering. (http://childrengrowup.wordpress.com/ 2012/06/26/inilah-penyebab-kematianbayi-paling-sering/, diakses tanggal 25 Nov 2012).

23. Sony Prabowo. 2011. Sekilas Tentang Persalinan Prematur. (http://majalahkesehatan.com/sekilastentang-persalinan-prematur/, diakses tanggal 26 Nov 2012).

24. Sumarah,Y N. 2008. Asuhan Kebidanan Pada Ibu Bersalin. Yogyakarta : Fitramaya.

25. Sujiyatini. 2009. Asuhan Patologi Kebidanan. Yogyakarta: Nuka Medika.

26. Steven P. Shelov, dkk. 2005. The American Academy of Pediatrics : Panduan Lengkap Perawatan untuk Bayi dan Balita. Jakarta : Arcan.

27. Saifuddin. 2009. Buku Acuan Pelayanan Kesehatan Maternal dan Neonatal. Jakarta : Yayasan Bina Pustaka Sarwono Prawirohardjo.

28. Varney, Helen. 2007. Buku Ajar Asuhan Kebidanan. Edisi 4. Jakarta : EGC.

29. Widyastuti, Y. 2009. Kesehatan Reproduksi. Yogyakarta: Fitramaya.

30. Winkjosastro Hanifa Prof. Dr. Sp.Og. 2007. Ilmu Kebidanan Edisi ke-3. Jakarta : Yayasan Bina Pustaka Sarwono Prawirohardjo.

31. Wiroatmodjo. 1994. Pedoman Diagnosa dan Terapi Lab/UPF Ilmu Kesehatan Anak. Surabaya : Fakultas Kedokteran Universitas Airlangga. 
Cite This Article As: Mayasari, B., Arismawati, D.F., Idayanti, T., Wardani, R.A. Hubungan Persalinan Prematur Dengan Kejadian Asfiksia Neonatorum Di Ruang Bersalin RSU Dr. Wahidin Sudiro Husodo Kota Mojokerto. Nurse and Health: Jurnal Keperawatan 2018; 7(1): 42-50. 